\title{
Improvement of cervical dentin hypersensitivity after two different treatments
}

\author{
Redução da dor decorrente da hipersensibilidade dentinária cervical após dois tratamentos \\ Maysa Santana Cavalcanteㄹ, Thainá Barbosa Pereira1, João Francisco Tenório Neto¹, Natanael Barbosa dos Santos¹, Camila Maria \\ Beder Ribeiro ${ }^{1}$, Luiz Henrique Carvalho Batista ${ }^{1}$
}

DOI 10.5935/1806-0013.20150052

\section{ABSTRACT}

BACKGROUND AND OBJECTIVES: Cervical dentin hypersensitivity is a routine clinical condition caused by dentin exposure to the oral environment and sensitivity caused by the ingestion of cold, sweet or sour foods, which induces localized, acute and brief pain. This study aimed at clinically evaluating the efficacy of two treatments to improve cervical dentin hypersensitivity, as well as the duration of their effects.

METHODS: The study was developed as a clinical, doubleblind and comparative study where 14 patients with cervical dentin hypersensitivity treated in the Clinic School of Dentistry of the University Center Cesmac were selected. Participants were divided in two groups of seven individuals. The first group was submitted to treatment with $5 \%$ potassium nitrate desensitizing (Nano P'-FGM) and the second group received fluoride varnish applications (Fluorniz-SS White). Both treatments have followed manufacturers' instructions.

RESULTS: Clinical evaluations were performed 7, 14, 21 days and 1 month after treatment. After statistical analysis of results, it was possible to conclude that products have improved initial cervical dentin hypersensitivity in studied dental elements after their applications and that the desensitizing effect of potassium nitrate was longer lasting as compared to fluoride varnish.

CONCLUSION: Potassium nitrate desensitizing effect was longer lasting as compared to fluoride varnish.

Keywords: Dentin hypersensitivity, Gingival recession, Periodontal therapy.

\footnotetext{
1. Centro Universitário, Centro de Estudos Superiores de Maceió, Maceió, AL, Brasl.

Submitted in May 23, 2015.

Accepted for publication in October14, 2015.

Conflict of interests: none - Sponsoring sources: none.

Correspondence to:

Camila Maria Beder Ribeiro

Pós-Graduaçáo do Centro Universitário Cesmac

Rua Cônego Machado, 918 - Farol

57051-160Maceió, AL, Brasil.

E-mail: camilabeder@hotmail.com

(C) Sociedade Brasileira para o Estudo da Dor
}

\section{RESUMO}

JUSTIFICATIVA E OBJETIVOS: A hipersensibilidade dentinária cervical é uma condição clínica rotineira na atualidade que decorre da exposiçáo da dentina ao meio bucal e sensibilidade causada após a ingestão de alimentos frios, doces ou ácidos, o que ocasiona dor localizada, aguda e de curta duraçấo. O objetivo deste estudo foi analisar clinicamente a eficácia de dois tratamentos utilizados na redução da hipersensibilidade dentinária cervical, bem como a duração dos seus efeitos.

MÉTODOS: O estudo foi desenvolvido como um ensaio clínico duplamente encoberto comparativo, onde foram selecionados 14 pacientescom hipersensibilidade dentinária cervical, atendidos na Clínica Escola de Odontologia do Centro Universitário Cesmac. Os participantes foram divididos em dois grupos com 7 integrantes cada. O primeiro grupo foi submetido ao tratamento com o dessensibilizante à base de nitrato de potássio a 5\% (Nano $\mathrm{P}^{\circ}$-FGM) e no segundo grupo foi aplicado o verniz fluoretado (Fluorniz-SS White). Em ambos os tratamentos foram seguidas as instruçóes dos fabricantes.

RESULTADOS: As avaliaçôes do quadro clínico ocorreram aos 7, 14, 21 dias e 1 mês. Após a análise estatística dos resultados pôde-se concluir que ambos os produtos apresentaram reduçáo clínica inicial no quadro de hipersensibilidade dentinária cervical nos elementos dentais pesquisados após as suas aplicaçôes e que o efeito do dessensibilizante à base de nitrato de potássio foi mais duradouro do que o do verniz fluoretado.

CONCLUSÃO: O efeito de dessensibilização com base de nitrato de potássio foi mais durável do que o do verniz fluoretado. Descritores: Hipersensibilidade da dentina, Recessão gengival, Terapia periodontal.

\section{INTRODUCTION}

Cervical dentin hypersensitivity (CDHS) may be defined as localized, acute and brief toothache affecting 35\% of the world population, that is, one out of every three individuals has this disorder, with predominance in the age group of 30 years and equally affecting males and females ${ }^{1-5}$. Youngsters have higher incidence of CDHS because they have thinner dentin layer as compared to the elderly, thus less effective dentinal tubules sealing ${ }^{6}$.

Tooth has structures, such as enamel, dentin and root cement, which protect nervous structures responsible for propagating pain in the presence of physical or chemical injuries. The loss 
of enamel and/or root cement, and consequent exposure of dentin to the oral environment are, together, major responsible for $\mathrm{CDHS}^{2}$.

The etiology of the loss of structures protecting tooth nervous tissues is varied and may be caused by incorrect tooth brushing, occlusal traumas, attrition, abrasion, erosion, gingival recession, acid foods and beverages, abrasive toothpastes and low oral hygiene level ${ }^{2,6}$.

CDHS is characterized by exaggerated painful response to thermal (heat and cold), chemical (acid, sweet and salty foods) and mechanical (teeth brushing and dental tools) stimuli, in addition to dehydration (air jet of dental equipment and mouth breathing $)^{1}$, and may vary from mild discomfort to severe pain ${ }^{2,7}$. Clinically, CDHS may be diagnosed by mechanical test (explorer probe) or dehydration (air jet of dental equipment $)^{8}$.

Theories have been proposed to explain DCHS pain mechanism, however the most widely accepted is the hydrodynamic theory proposed by Brannstrom (1963) where it is stated that this sensitivity is the product of fast movement of fluid inside dentinal tubules which happens when stimuli are applied to dentin in teeth with non-carious cervical injuries, thus activating pulp nervous fibers ${ }^{9-12}$.

According to Sobral ${ }^{1}$ and Silva et al. ${ }^{13}$, DCHS may be mistaken for other clinical situations with the same symptoms, such as cracked tooth syndrome, restoration fractures, caries, postoperative sensitivity, occlusal trauma and reversible or irreversible pulp inflammatory processes. So, dentists should obtain an accurate history, intraoral (mechanical and dehydration tests) and radiological exams to rule out any other clinical condition similar to DCHS.

Proposed therapies to improve or eliminate DCHS pain are in general not effective ${ }^{14-22}$. In 1935, Grossman ${ }^{14}$ has defined requirements for hypersensitivity management to be effective and which are valid to date: biocompatibility, not causing pain, fast and easy to apply, fast action, not staining teeth and being effective in the long term. This is a Dentistry challenge: finding a very effective therapy, which eliminates hypersensitivity painful sensation and prevents recurrence $e^{4,15,16}$.

There are currently in the market several options to manage DCHS ${ }^{15,17,18}$. These products, such as fluoride varnish, are of easy access, low cost and are available in public services and Dentistry schools. Another product, similar to previous one, is $5 \%$ potassium nitrate desensitizer, very popular in private clinics and used in more recent DCHS studies ${ }^{10,19,20}$. These products have different action mechanisms. Fluoride varnish (Fluorniz ${ }^{\circ}$ may be classified as tubular occlusion agent ${ }^{6}$.

Sodium fluoride, present in its composition, when in contact with dental structure calcium, forms calcium fluoride crystals which precipitate and occlude dentinal tubules, inhibiting the transmission of painful sensitivity ${ }^{7}$. Desensitizing agent based on $5 \%$ potassium nitrate (Nano $\mathrm{P}^{\circ}$ ), on the other hand, in addition to occlusive action, is also classified as agent changing pulp sensory activity, that is, it has neural action ${ }^{6}$. Potassium nitrate present in its composition directly acts on nervous fibers, changing neural components excitability and depolarizing nervous terminations, thus decreasing dentinal sensitivity ${ }^{10,18,21}$.

In light of the above, this study aimed at clinically evaluating two treatments to decrease DCHS as well as diagnostic tests and duration of their effects.

\section{METHODS}

This was a double-blind comparative clinical trial carried out in the Clínica Escola de Odontologia, Centro Universitário Cesmac.

Sample was obtained by convenience as from medical records of patients submitted to dental treatment between 2011 and 2013. Individuals with gingival recession and/or DCHS informed in medical records were invited by telephone to participate in a screening process.

Inclusion criteria were all individuals with gingival recession Miller class I or II with DCHS, systemically healthy and with physical and mental conditions to understand and adhere to proposed treatment.

Exclusion criteria were patients under analgesics and anti-inflammatory drugs, with caries, dental fractures, pulpitis and defective restorations in the quadrant of the tooth to be evaluated, as well as patients with ulcerating gingivitis, stomatitis or any other oral cavity injury.

The first 14 patients with diagnosed DCHS, meeting inclusion criteria and with no exclusion criteria were selected. Participants were of both genders with ages between 20 and 40 years.

Selected patients came to the clinic and received all necessary information for the study, such as guidance about oral hygiene and absence of acid diet, since this could remove tubular dentin and expose dentinal tubules to oral environment and cause DCHS. History was updated and, when necessary, radiological exams confirmed or ruled out diseases with symptoms similar to DCHS.

After the signature of the Free and Informed Consent Term (FICT), the study was started. Individuals were allocated by means of a draft in two equal groups, A and B. Patients were numbered from 1 to 14 and papers were placed in a plastic bag. Then, a researcher not participating in the practical part of the study has picked seven numbers to form group A. Remaining seven formed group B.

Group A received 5\% potassium nitrate desensitizer and group B received fluoride varnish, to treat DCHS.

Just one tooth was chosen per patient for the study: the one with patients' complaint. To record tooth sensitivity, dentin hypersensitivity level scale based on the literature ${ }^{16}$ and adapted for this study was used, as follows: level zero - no discomfort; level 1 - mild discomfort (insignificant pain); level 2 - moderate discomfort (pain during application of stimuli and then ceased) and level 3 - marked discomfort (severe pain during application of stimuli and lasting for more than 10 seconds after its removal).

To evaluate this discomfort, a researcher blind to the treatment to be used in each patient has used dehydration with air 
jet and mechanical stimuli with explorer probe.

Both treatment groups were:

- Group A: application of 5\% potassium nitrate desensitizer according to manufacturer's instructions, that is: after previous tooth prophylaxis with rubber cup and pumice, the area where the product was to be applied was washed and dried, and using relative isolation, the product was directly applied to the external surface of the tooth with adequate pointer supplied by the manufacturer. According to the protocol, product was rubbed on dental surface for 10 seconds with adapted rubber cup in low rotation and medium speed. Material remained at rest for 5 minutes and after this time excesses were removed with cotton roller. Patient was oriented not to ingest solid food for up to 30 minutes after material application. This procedure was carried out in an office of the Clínica Escola de Odontologia, Centro Universitário Cesmac, in three applications with 3-day intervals, also according to manufacturer's instructions.

- Group B: application of fluoride varnish, also according to manufacturer's instructions: after previous tooth prophylaxis with rubber cup and pumice, the area was washed and dried and a thin varnish layer was applied with microbrush; nonadhered excess was removed. Patient was oriented not to ingest solid food and not to brush treated teeth for the next 12 hours after application. This procedure was carried out in an office of the Clínica Escola de Odontologia, Centro Universitário Cesmac, in two applications with 7-day intervals, also according to manufacturer's instructions.

At treatment completion, four evaluations of dentin hypersensitivity were performed: 7, 14, 21 and 30 days after treatment. During such evaluations, teeth were again submitted to already described tests (mechanical and dehydration), by the same evaluator blind about performed treatments. After collecting these data, tables were prepared and sent to statistical analysis, where Kruskall-Wallis test and Dunn post-test were applied because these were non-parametric data. Confidence interval was 95\% $(\mathrm{p}<0.05)$.

This study was approved by the Research Ethics Committee (CEP) under protocol 1458/2012.

\section{RESULTS}

After treatment and collection of revaluation data, these were sent to statistical analysis and have produced the following results:

Equal letters mean no statistically significant difference.

Results have shown that in the potassium nitrate desensitizer group (group A), there has been statistically significant improvement of dentin sensitivity, both with dehydration and mechanical tests (with explorer probe), difference represented by different letters $\mathrm{X}$ and $\mathrm{Y}$ (Tables 1 and 2).

In comparing between groups, there has been statistically significant difference in group $A$ in initial evaluation with dehydration test, and in group B this difference was present at 7 days (Table 1). Table 2 has shown no difference between groups.
Table 1. Means of hypersensitivity level scores at baseline (diagnosis) and after proposed treatments after dehydration test (air jet with triple syringe)

\begin{tabular}{lcc}
\hline Time & \multicolumn{2}{c}{ Proposed treatment } \\
& Group A* & Group B \\
\hline Initial (days) & $2 \pm 0.81^{\mathrm{x}}$ & $1.85 \pm 0.69^{\curlyvee}$ \\
7 & $1.14 \pm 0.69^{\mathrm{x}}$ & $1 \pm 0.57^{\mathrm{y}}$ \\
14 & $0.85 \pm 0.69^{\mathrm{x}}$ & $1.14 \pm 089^{\curlyvee}$ \\
21 & $0.71 \pm 0.75^{\mathrm{\gamma}}$ & $1.42 \pm 0.97^{\curlyvee}$ \\
30 & $0.71 \pm 0.75^{\mathrm{x}}$ & $1.42 \pm 0.97^{\curlyvee}$ \\
\hline
\end{tabular}

Different letters represent statistically significant differences $(p<0.05)$. Kruskall-Wallis test and Dunn post-test with significance level of $5 \%$; *Values in Mean \pm SD.

Table 2. Means of hypersensitivity level scores at baseline (diagnosis) and after proposed treatments after mechanical test (explorer probe)

\begin{tabular}{|c|c|c|}
\hline \multirow[t]{2}{*}{ Time } & \multicolumn{2}{|c|}{ Proposed treatment } \\
\hline & Group A* & Group B* \\
\hline Initial (days) & $0.42 \pm 0.53^{x}$ & $0.71 \pm 0.48^{Y}$ \\
\hline 7 & $0.28 \pm 0.48^{x}$ & $0.71 \pm 0.48^{\curlyvee}$ \\
\hline 14 & $0.14 \pm 0.37^{x}$ & $0.42 \pm 0.53^{Y}$ \\
\hline 21 & $0.14 \pm 0.37^{x}$ & $0.42 \pm 0.53^{\Upsilon}$ \\
\hline 30 & $0.14 \pm 0.37^{x}$ & $0.42 \pm 0.53^{\Upsilon}$ \\
\hline
\end{tabular}

Different letters represent statistically significant differences $(p<0.05)$. Kruskall-Wallis test and Dunn post-test with significance level of $5 \%$; *Values in Mean \pm SD.

\section{DISCUSSION}

DCHS affects many people and there are currently several options in the market for its treatment ${ }^{15,17,18}$. Products available in the market have different action mechanisms $s^{6,7,10,18,21}$. Our study has used fluoride varnish (Fluorniz ${ }^{\circ}$ ) and 5\% potassium nitrate desensitizer (Nano $\mathrm{P}^{\circ}$ ), which are able to decrease dentin sensitivity ${ }^{10,18,21}$.

Our study has not considered the use of control groups, since a positive control group was not applicable, because currently there is no golden standard treatment for DCHS. On the other hand, a negative control group would be contraindicated, because using placebo for pain hurts bioethcis and is disrespect to patients who have freely agreed to participate in the study aiming at attenuating or even eliminating inconvenient DCHS symptoms.

Our results have shown that group A had statistically significant dentin sensitivity improvement by dehydration test. This result might be credited to its already explained mode of action and is in line with literature results ${ }^{19}$. Even other products, with different modes of action but with similarities for having neural action, have also shown similar results ${ }^{16}$.

Gondim et al. ${ }^{10}$ have described a case where they used two different desensitizers in two different teeth of a same patient, being one of them the desensitizer used in our study. There has been immediate sensitivity decrease after the first application and total elimination of sensitivity after the three recommended applications. Desensitizer effect is immediate after its application and has long-lasting effect due to the action of 
saliva on hydroxyapatite nanoparticles, representing effective treatment, similar to what has been observed in our study.

When diagnosis was with air jet, group A had significant improvement 7 days after applications and which lasted throughout this study, with continuity of obtained results, without statistical differences between other intervals of data collected during other evaluations, similar to results found by Gondim et al. ${ }^{10}$.

Group B had initial DCHS decrease by dehydration test, however this sensitivity has returned to statistically similar levels of baseline levels. When obliterating dentinal tubules with unstable particles such as calcium fluoride, these may easily dissociate through teeth brushing and/or acid foods. Another explanation for this inefficiency could be the fact that calcium fluoride crystals produced by calcium fluoride, have relatively small diameter $(0.05 \mathrm{~mm})^{20,22}$.

Pinto et al. ${ }^{22}$ have evaluated in vitro the effect of substances used to treat dentin hypersensitivity with regard to residual diameters of dentinal tubules. Three groups were used: 2\% potassium nitrate with $2 \%$ sodium fluoride (G1), varnish with 5\% sodium fluoride (G2) and teeth brushing with toothpaste $(\mathrm{G} 3)$. Residual tubules diameters were smaller in G1 $(0.91 \pm 0.35)$, followed by G2 $(1.14 \pm 0.34)$ and G3 $(1.26 \pm 0.37)$, which shows decreased varnish effect as days went by.

With explorer probe (mechanical stimulation) diagnosis, it was observed that values were neither positively nor negatively changed throughout the study for both groups. This test was less effective to diagnose DCHS as compared to air jet with tripe syringe, as shown by baseline data of both groups $A$ and B, where DCHS means were much higher with air jet as compared to mechanical test. Dehydration inside tubules and consequent drying of dentinal fluid seem to decisively contribute for higher level of sensitivity.

At evaluation completion, it was observed that group A had statistically significant DCHS improvement, fact which has not been observed in group B. However, it has to be stressed that further studies using longer evaluation times are needed.

\section{CONCLUSION}

Both products, $5 \%$ potassium nitrate desensitizer and fluoride varnish, had initial clinical improvement of DCHS in studied teeth after their application.

Desensitizing effect of $5 \%$ potassium nitrate was longer-lasting as compared to fluoride varnish.
Dehydration test with air jet and triple syringe was more effective to diagnose and record DCHS intensity as compared to mechanical test with explorer probe.

\section{REFERENCES}

1. Sobral MAP. Lesōes cervicais não cariosas e hipersensibilidade dentinária cervical. In: Garone Netto N, et al. (editores) Introdução a Dentística Restauradora. São Paulo: Santos; 2003. 265-83p.

2. Estrela C, Pesce HF, Silva MT, Fernandes JM, Silveira HP. Análise da redução da dor pós-tratamento da hipersensibilidade dentinária. ROBRAC. 1996;6(17):4-9.

3. Almeida EC, Menezes MR, Aguiar CM. Tratamento da hiperestesia dentinária com laser de GaAIAs. Odontol Clin Cient. 2006;5(2):143-52.

4. Hotta TH, Marchesan JT, Santos TM, Silva MA, Silva RS, Pécora JD. Uso de laser e placa oclusal na sensibilidade dentinária de bruxômanos. RGO. 2006;54(2):195-8.

5. Swift EJ Jr, May KN Jr, Mitchell S. Clinical evaluation of Prime \& Bond 2.1 for treating cervical dentin hypersensitivity. Am J Dent. 2001;14(1):13-6.

6. Matias MN, Leăo JC, Menezes Filho PF, Silva CH. Hipersensibilidadedentinária: uma revisão de literatura. Odontol Clín Cient. 2010;9(3):205-8.

7. Aguiar FH, Giovanni EM, Monteiro FH, Villalba H, Melo JJ, Tortamano N. Hipersensibilidade dentinária- causas e tratamento. Uma revisão da literatura. Rev Inst Ciênc Saúde. 2005;23(1):67-71.

8. Peixoto LM, Daleprane B, Batitucci MH, Sanglard L, Pazinatto FB. Tratamento da hipersensibilidade dentinária cervical. Rev Bras Pesq Saúde. 2010;12(2):69-74.

9. BränströmM. Sensory mechanism in dentine. In: Anderson JD. (editor) A hydro dynamic mechanism in the transmission of pain producing stimuli through the dentine. Oxford: Pergammon Press 1963 apud Matias MNA, Leão JC, Filho PFM, Silva CHV. Hipersensibilidadedentinária: uma revisāo de literatura. Odontol Clín Cient. 2010;9(3):205-8.

10. Gondim RC, Lima DM, Costa JF, Bauer JR. Hipersensibilidade dentinária de lesōes cervicais não cariosas: abordagens terapêuticas no controle da dor. Rev Pesq Saúde. 2011;12(1):52-5.

11. Conceição EN, Scur A, Vidor MM. Avaliação clínica do uso de ionômero de vidro na hipersensibilidade dentinária em lesôes de abrasão. Rev Bras Odontolol. 1994;51(4):39-42.

12. Barbosa RP, Santos RL, Gusmão ES. Terapias para controle de lesōes não cariosas hipersensíveis. Odontol Clín Científ. 2005;4(3):174-6.

13. Silva CH, Souza FB, Guimarães RP, Lyra AMV, Loretto SC, Braz R, et al. Diagnóstico e plano de tratamento. In: Busato ALS. Dentística: Filosofia, Conceitos e Prática Clinica Grupo Brasileiro de Professores de Dentística. São Paulo: Artes Médicas; 2005. 95-124p.

14. Grossman LE. The treatment of hypersensitive dentine. J. Am Dent Assoc. Chicago 1935; 22(4):592-602 apud Matias MNA, Leão JC, Filho PFM, Silva CHV. Hipersensibilidade dentinária: uma revisăo de literatura. Odontol Clín-Cient. 2010;9(3):205-8.

15. Faria GJ, Villela LC. Etiologia e tratamento da hipersensibilidade dentinária em dentes com lesôes cervicais não cariosas. Rev Biociência Taubaté. 2000;6(1):21-7.

16. Garcia CH, Kahn S, Galan Jr J, Namen FM, Machado WA. Avaliaçấo clínica da hipersensibilidade dentinária após tratamento com dessensibilizantes comerciais. Periodontia. 2009;19(2):78-85.

17. Barbosa LP, Prado Jr RR, Mendes RF. Lesôes cervicais năo-cariosas: etiologia e opçôes de tratamento restaurador. Rev Dentística. 2009;8(18):1-10.

18. Tonetto MR, Dantas AA, Bortolini GF, Fabris M, Campos EA, Andrade M. Hipersensibilidade dentinária cervical: em busca de um tratamento eficaz. Rev Odontol. 2012;24(3):190-9.

19. Wang L, Magalhães AC, Calabria MP, Francisconi LF, Dantas LM, Araújo DF, et al. Análise clínica da reduçáo de hiperestesia dentinária cervical pela pasta Dessensibilize Nano P: resultados preliminares. 2012. http://fgm.ind.br/site/ver_artigo. php?id=1598\&lng=pt.

20. Santos AP, Pereira MN, Leite FP, Oliveira JM, Chaves MG. Um sintoma preocupante: a hipersensibilidade dentinária. Rev Bras Odontol. 2010;67(2):242-6.

21. Vale IS, Bramate AS. Hipersensibilidade dentinária: diagnóstico e tratamento. Rev Odontol USP. 1997;11(3):207-13

22. Pinto SC, Pochapski MT, Wambier DS, Pilatti GL, Santos FA. Análise de substâncias dessensibilizantes na permeabilidade da dentina e obliteração de túbulos dentinários estudo in vitro. Rev Periodontia. 2008;17(3):41-8. 